\title{
Growing evidence related to the association between endocrine disruptor chemicals and stillbirth
}

\author{
Francesco PISCIOLI ${ }^{1}$, Teresa PUSIOL ${ }^{1}$, Anna Maria LAVEZZI ${ }^{2}$, Luca RONCATI ${ }^{3}$
}

According to the definition of the United Nations Environment Programme and of the World Health Organization, the endocrine disruptor chemicals (EDCs) are foreign substances that alter the homeostasis of the endocrine system, causing adverse effects in a previously (up to the time of the exposure) healthy orga$n^{n i s m}{ }^{1}$. They can influence the endocrine system, acting as hormonal molecules ${ }^{2}$. They are bio-persistent because of their degradation resistance in the environment and they can be found in pesticides, metals, additives or contaminants of food, deep and superficial waters, and personal care products ${ }^{3}$. Today, the role of EDCs in many human diseases is under investigation and particular attention has been focused on maternal, fetal, and childhood exposure ${ }^{4-6}$. In this regard, we have investigated, by gas chromatographymass spectrometry (GC-MS), the concentration of EDCs in 51 cortex specimens obtained from 43 cases of sudden intrauterine unexplained death syndrome (SIUDS) and 8 cases of sudden infant death syndrome (SIDS), occurred in the Northeast Italy, a region notoriously devoted to fruit cultivation ${ }^{7}$. More in detail, 25 EDCs have been subjected to GC-MS, following the standard protocols. Among the analyzed substances, five organochlorine pesticides, that is $\alpha$-chlordane, $\gamma$-chlordane, heptachlor, dichlorodiphenyldichloroethylene, dichlorodiphenyltrichloroethane, and the two most sold organophosphorus pesticides (OPPs), chlorpyrifos and chlorfenvinfos, have been detected at part-per-billion (ppb) levels in 15 cases with SIUDS and 3 cases with SIDS. Therefore, environmental EDCs are able to cross the placental barrier, and enter into fetal and neonatal brains ${ }^{8}$. Here, they can induce developmental alterations, especially in the basal nuclei, the major controllers of the vital functi- ons, and impairment of the receptorial expression of orexin ${ }^{9}$. These findings imply a conceptual redefinition of the fetal-placental and fetal blood-brain barriers (not insuperable barriers, but rather layers for delayed absorption), and open the way for a possible EDC involvement in stillbirth, too.

\section{REFERENCES}

1. United Nations Environment Programme, World Health Organization. Endocrine systems and endocrine disruption. In: Bergman Å, Heindel JJ, Jobling S, Kidd KA, Zoeller RT (eds). State of the Science of Endocrine Disrupting Chemicals 2012. Geneva, Switzerland, WHO Press 2013:4-6.

2. Pusiol T, Lavezzi A, Matturri L, et al. Impact assessment of endocrine disruptors on sudden intrauterine and infant death syndromes. Eur J Forensic Sci 2016;3:8-15. http://dx.doi.org/10.5455/ejfs.197968

3. Roncati L, Termopoli V, Pusiol T. Negative role of the environmental endocrine disruptors in the human neurodevelopment. Front Neurol 2016;7:143. http://dx.doi.org/10.3389/fneur.2016.00143

4. Roncati L, Piscioli F, Pusiol T. The endocrine disrupting chemicals as possible stillbirth contributors. Am J Obstet Gynecol 2016;215:532-3.

http://dx.doi.org/10.1016/j.ajog.2016.05.031

5. Roncati L, Piscioli F, Pusiol T. The endocrine disruptors among the environmental risk factors for stillbirth. Sci Total Environ 2016;563-564:1086-7.

http://dx.doi.org/10.1016/j.scitotenv.2016.04.214

6. Roncati L, Barbolini G, Pusiol T, et al. New advances on placental hydrops and related villous lymphatics. Lymphology 2015;48:28-37.

7. Roncati L, Pusiol T, Piscioli F, et al. The first 5-year-long survey on intrauterine unexplained sudden deaths from the Northeast Italy. Fetal Pediatr Pathol 2016;16:1-12. http://dx.doi.org/10.1080/15513815.2016.1185751

8. Lavezzi AM, Ferrero S, Matturri L, et al. Developmental neuropathology of brainstem respiratory centers in unexplained stillbirth: What's the meaning? Int J Dev Neurosci 2016;53:99-106. http://dx.doi.org/10.1016/j.ijdevneu.2016.06.007

9. Lavezzi AM, Ferrero S, Roncati L, et al. Impaired orexin receptor expression in the Kölliker-Fuse nucleus in sudden infant death syndrome: possible involvement of this nucleus in arousal pathophysiology. Neurol Res 2016;29:1-11. http://dx.doi.org/10.1080/01616412.2016.1201632

Received: 28.08.2016

Accepted: 03.10.2016

${ }^{1}$ Provincial Health Care Services, Institute of Pathology, Santa Maria del Carmine Hospital, Rovereto (TN)

${ }^{2}$ Department of Biomedical, Surgical and Dental Sciences, Lino Rossi Research Center, University of Milan, Milan (MI)

${ }^{3}$ Department of Diagnostic and Clinical Medicine and of Public Health, University of Modena and Reggio Emilia, Modena (MO)

Yazışma adresi: Luca Roncati, MD, PhD, Department of Diagnostic and Clinical Medicine and of Public Health, Division of Pathology, University of Modena and Reggio Emilia, Policlinico Hospital, I-41124, Modena, Italy

e-mail: emailmedical@gmail.com 